\title{
Virtual Reality Berbasis Video 360 Derajat pada Tari-Tarian Adat Suku Minahasa
}

\author{
Xenna Rambing ${ }^{1)}$, Virginia Tulenan ${ }^{2)}$, Xaverius Najoan ${ }^{3)}$ \\ 1,2,3 Teknik Informatika Universitas Sam Ratulangi Manado, Indonesia. \\ Email : 120216127@ student.unsrat.ac.id ${ }^{1)}$, virginia.tulenan@gmail.com ${ }^{2}$ Xaverius.najoan@ gmail.com ${ }^{3)}$
}

\begin{abstract}
Abstrak - Pelestarian Budaya lokal merupakan salah satu bentuk sikap nasionalisme yang harus ditanamkan kepada diri sendiri juga kepada anak-anak usia dini tanpa menghiraukan perkembangan dunia saat ini. Khususnya pada Budaya seni Tarian suku Minahasa yang semakin pudar seiring perkembangan zaman.Sebagai contoh minat mempelajari budaya pada anak usia dini sudah dihiraukan oleh orang tua maupun guru akibat dari teknologi yang sudah menawarkan visualisasi media yang lebih menarik dan atraktif. Maka dibutuhkan sebuah media interaktif dalam bentuk aplikasi visual yang menyesuaikan perkembangan teknologi pada zaman ini. Berdasarkan masalah tersebut maka dari itu penulis membuat sebuah aplikasi Virtual Reality berbasis video 360 derajat pada tarian adat suku Minahasa dengan menggunakan metode interactive multimedia system of desain and development (IMSDD) dan google cardboard sebagai perangkat dalam visualisasi video.Dengan menerapkan media tersebut maka minat mempelajari seni tari dalam budaya Minahasa akan lebih menarik.
\end{abstract}

Kata kunci : Budaya, Suku Minahasa,Video 360, Tarian, Virtual Reality.

\section{PENDAHULUAN}

Suku Minahasa merupakan suku yang berasal dari provinsi Sulawesi Utara yang kaya akan budaya dan tradisi yang melekat sejak zaman dahulu, menurut kamus besar Bahasa Indonesia suku dapat diartikan sebagai golongan bangsa sebagai bagian dari bangsa yang besar, dapat diartikan juga suku Minahasa merupakan suku yang memiliki suatu aturan juga budaya tersendiri dari suatu bangsa yang besar, salah satu budaya yang masih melekat diantaranya adalah budaya Menari/seni Tari yang pada umumnya digunakan para leluhur untuk upacara menyambut tamu-tamu penting, juga sering digunakan sebagai ritual adat sesuai kepercayaan dari suku Minahasa.

Kesadaran masyarakat Minahasa pada budaya sendiri sudah sangat menurun akibat perkembangan Teknologi yang sudah semakin berkembang pesat dan semakin mempengaruhi masyarakat, hal ini menimbulkan berkurangnya praktek juga materi pembelajaran tentang budaya daerah , demi memperbaiki ini penulis ingin membuat suatu media visual berupa Video 360 derajat tentang budaya Minahasa khususnya tentang tari-tarian adat yang mampu menyampaikan informasi yang jelas dan edukatif. Video 360 merupakan video yang memperbolehkan penonton untuk melihat tampilan gambar visual secara 360 derajat ,teknologi ini sudah banyak digunakan dalam salah satu cara memvisualisasikan suatu kegiatan dengan tampilan yang dapat menampilkan keseluruhan sudut pandang yang ada di sekitar kita sehingga membuat pengalaman menonton video menjadi lebih menarik.

Kombinasi video 360 dengan budaya suatu suku dapat menciptakan suatu media yang dapat memperkenalkan juga mengangkat potensi budaya suatu daerah secara menarik dan lebih mudah untuk dipelajari dan dipahami. Oleh karena itu, dalam proyek tugas akhir ini penulis akan membuat Virtual Reality berupa video $360^{\circ}$ tentang Tari-tarian Adat yang berada pada suku Minahasa.

\section{LANDASAN TEORI}

\section{A. Suku Minahasa}

Suku Minahasa merupakan salah satu suku bangsa yang berada di negara Indoneisa yang bertempat di bagian timur laut Sulawesi Utara, Orang Minahasa sering menyebut diri Orang Manado/Touwenang karena banyak orang asli suku Minahasa tinggal di Kota Manado. Minahasa yang dulunya dikenal dengan nama "Malesung" berasal dari kata "Minaesa" yang berarti Persatuan. Daerah pemukiman nenek moyang orang asli suku Minahasa biasanya terdapat di sekitar pegunungan yang tersebar di daerah Sulawesi Utara.

\section{B. Tari Maengket}

Maengket merupakan salah satu tari-tarian adat yang berada di Sulawesi Utara asal dari suku Minahasa. Maengket merupakan diambil dari kata engket yang berarti pasang,nyalakan,buka jalan, kaitkan, dan sebagainya. Maengket merupakan suatu tarian yang sudah menjadi tradisi masyarakat Minahasa, dilakukan oleh kelompok yang menyanyi sambil menari bahkan saling berpeganggan tangan , dipimpin oleh seorang Kapel yang akan mengangkat suara pertama serta tambur sebagai pengiringnya.

\section{Multimedia}

Multimedia merupakan penggunaan komputer demi menyajikan dan menggabungkan teks, suara, gambar, animasi dan video dengan alat bantu (tool) dan koneksi (link) sehingga pengguna dapat bernavigasi, berinteraksi, berkarya dan berkomunikasi ${ }^{[7]}$.

Dibawah merupakan beberapa komponen dalam Multimedia : 


\section{Video}

Definisi video merupakan potongan gambar tunggal yang disebut frames. Hasil Pengolahan beberapa gambar yang membuat ilusi gambar bergerak karena otak tidak menangkap gambar secara individual. Dalam ukuran Frame Rate per Second (FPS) semakin besar FPS maka semakin halus gambar yang ditampilkan .secara sederhana sinkronasi Audio dengan rangkaian gambar akan menampilkan video dengan gambar visual yang memiliki suara

\section{Video 360}

Video 360 merupakan video yang dibuat oleh system kamera yang secara bersamaan merekam arah secara keseluruhan dengan rotasi 360 derajat,user dapat menggeser dan memutar sudut pandang 360 video untuk menonton dari sudut yang berbeda.

\section{Interaksi Manusia dan Komputer}

Interaksi Manusia dan Komputer adalah ilmu yang mempelajari tentang bagaimana manusia berinteraksi secara nyata dengan komputer dan pengaruh dari interaksi antara manusia dan komputer. tujuan dari interaksi manusia dan komputer yaitu perancangan dan evaluasi antarmuka pemakai ${ }^{[5]}$

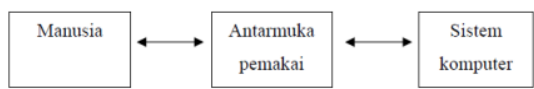

Gambar 1. User Interface

\section{E. Unity}

Unity 3D merupakan software yang biasanya diguakan developer untuk membuat game $3 \mathrm{~d}$ karena kemampuan yang mendukung hampir semua jenis platform diantaranya perangkat komputer, ponsel pintar android, iPhone, PS3, dan x-box ,unity secara rinci dapat digunakan untuk membuat video game $3 \mathrm{D}$, real time animasi 3D ,visualisasi arsitektur dan isi serupa yang interaktif lainnya ${ }^{[3]}$

\section{F. Android}

Android merupakan open source platform berbasis Linux yang dirancang untuk perangkat mobile. Sistem operasi Android dibangun dengan menggunakan bahasa pemrograman $\mathrm{C}$ dimana setiap aplikasi yang berjalan di atasnya, berjalan di atas application framework yang dibangun dengan menggunakan bahasa pemrograman Java dengan memanfaatkan Apache Harmony sebagai librarynya. $\left[{ }^{10}\right]$.

\section{G. Google Cardboard}

Google Cardboard merupakan perangkat pendukung Virtual Reality (VR) yang dikembangkan oleh google berbahan dasar karton yang dilipat dan menggunakan smartphone sebagai layarnya ${ }^{[2]}$.

\section{H. Interactive multimedia system of desain and development (IMSDD)}

Dalam penelitian ini, aplikasi yang akan dibangun melalui tahap-tahap model interactive multimedia system of desain and development (IMSDD) oleh Dastbaz (dalam Ahmad, 2011),. IMSDD terdiri dari beberapa tahapan, yaitu : Kebutuhan sistem, Perancangan Desain, Implementasi, Evaluasi.Dibawah merupakan gambaran skema tentang tahapan-tahapan model yang akan diterapkan pada penelitian kali ini.

\section{Virtual Reality}

Virual Reality (VR) merupakan suatu Teknologi yang menempatkan User pada gambar atau video yang memungkinkan User meningkatkan kesadaran secara situasional serta memperluas daya lihat, menangkap, serta menganalisa data virtual secara signifikan. Virtual Reality juga dapat didefinisikan sebagai realitas dunia maya yang memungkinkan pengguna dapat berinteraksi dengan suatu lingkungan yang disimulasikan oleh komputer, suatu teknologi yang mensimulasikan tiruan dari lingkungan yang sebenarnya dan yang ada dalam imaginasi.

Lingkungan realitas dunia maya terkini umumnya menyajikan pengalaman visual secara menarik, yang ditampilkan pada sebuah layar komputer atau melalui sebuah device yang mendukung teknologi ini, tapi beberapa simulasi mengikutsertakan tambahan informasi dalam bentuk visualisasi. ${ }^{[4]}$

\section{METODOLOGI PENELITIAN}

\section{A. Metodologi Penelitian}

Pembuatan aplikasi virtual reality berbasis video 360 derajat tari-tarian adat suku Minahasa ini menggunakan metode pengembangan aplikasi interactive multimedia system of desain and development (IMSDD).

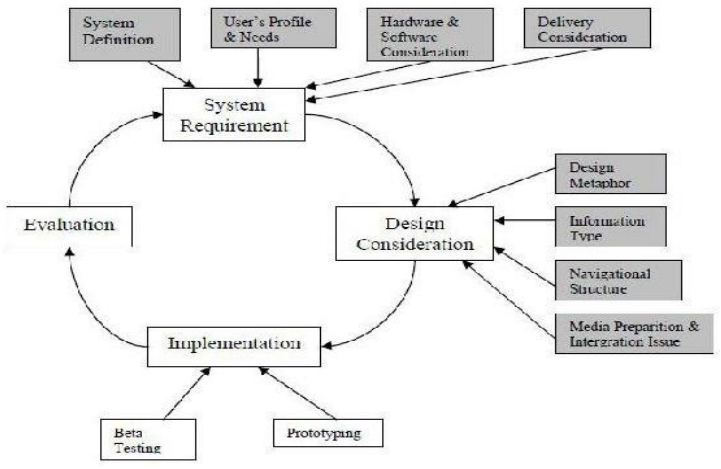

Gambar 2. Paradigma pembuatan interactive multimedia system of desain and development (IMSDD)

Pada tahap kebutuhan sistem, memiliki fungsi untuk menyediakan definisi system mengenai tujuan dan sasaran system yang akan dibuat dan kemudian memastikan siapa 
user dari sistem yang akan dibuat jika memiliki kebutuhan spesifik yang bisa dipertimbangkan.

Pada tahap Pertimbangan Desain, mengambarkan secara jelas detail dari desain, hal ini mencakup :

\section{Metafora Desain}

Memilih sebuah objek nyata untuk digunakan sebagai desain interface bagi system contohnya filem,buku,game,dll.

\section{Tipe Informasi}

Mendefinisikan tipe-tipe informasi yang perlu diintegrasikan kedalam system (teks, grafik, animasi, suara, video)

\section{Struktur Navigasi}

Menjelaskan strategi navigasi,termasuk struktur link dan fitur-fitur yang dapat menghindari disorientasi.

\section{Masalah Integrasi dan Persiapan Media}

Menjelaskan tipe dan fitur-fitur control yang dibutuhkan dalam system.

Pada tahap Implementasi, memiliki fungsi untuk membuat prototype dari system dan melakukan beta testing pada system Dan pada tahap Evaluasi, system akan dievaluasi berdasarkan tujuan awalnya

\section{B. Metode Pengumpulan Data}

Metode pengumpulan data yang dilakukan penulis dalam penelitian tugas akhir ini yaitu sebagai berikut :

\section{A. Data Primier}

Data yang didapatkan dengan melakukan wawancara tatap muka dengan kepala bagian yang berada di Dinas Kebudayaan Pemprov Sulawesi Utara juga tokoh Budaya adat Minahasa untuk memvalidasi informasi yang ditampilkan dalam aplikasi nanti.

\section{B. Data Sekunder}

Data yang didapatkan melalui studi literatur dan sumber dari internet.

\section{HASIL DAN PEMBAHASAN}

\section{A. Tahap Kebutuhan Sistem}

Dalam Tahapan kali ini penulis mendeskripsikan kebutuhan dari sistem yang akan digunakan pada proses membangun aplikasi dalam hal ini yaitu deskripsi kebutuhan system juga kebutuhan hardware dan software pada tahap pengembangan.
Tabel 1. Deskripsi Kebutuhan Sistem

\begin{tabular}{|c|c|}
\hline Judul & Maengket 360 \\
\hline Definisi & $\begin{array}{l}\text { - Media pengenalan juga } \\
\text { pelestarian seni Tari } \\
\text { Maengket.Berisi informasi } \\
\text { tentang Tarian Maengket } \\
\text { - Berisi informasi tentang } \\
\text { Tarian Maengket }\end{array}$ \\
\hline Pengguna Akhir & $\begin{array}{l}\text { Pengguna yang memiliki } \\
\text { smartphone }\end{array}$ \\
\hline Durasi & $\begin{array}{lccc}- & \text { Babak } & 1 & \text { berdurasi } \\
00: 07: 48 & & \\
-\quad \text { Babak } & 2 & \text { berdurasi } \\
\text { 00:05:08 } & & \\
-\quad \text { Babak } & 3 & \text { berdurasi } \\
\text { 00:05:54 } & & \end{array}$ \\
\hline Authoring Tools & $\begin{array}{l}\text { - Unity 3D V5.6 } \\
\text { - Adobe Premier Pro } \\
\text { Gear } 360 \text { Action Director }\end{array}$ \\
\hline $\begin{array}{c}\text { Deskripsi } \\
\text { Sistem }\end{array}$ & $\begin{array}{l}\text { Virtual Reality berbasis } \\
\text { Video } 360 \text { pada Tari } \\
\text { Maengket anderbentuk } \\
\text { aplikasi Interaktif yang } \\
\text { menampilkan Tarian } \\
\text { Maengket } \\
\text { keseluruhan } 3 \text { babak yang } \\
\text { dalam setiap scene babak } \\
\text { terdapat Tombol informasi } \\
\text { mengenai arti dari gerakan } \\
\text { tari yang ditampilkan }\end{array}$ \\
\hline
\end{tabular}

Tabel 2. Tahap Pengembangan

\begin{tabular}{|c|c|}
\hline Harc & Soft \\
\hline Laptop Lenovo g40-70 & - Sistem op \\
\hline Spes & \multirow{13}{*}{$\begin{array}{l}8.1 \\
\text {-Adobe Photoshop CS6 } \\
\text { Digunakan untuk } \\
\text { membuat Icon } \\
\text { - Adobe Premier PRO CC } \\
\text { Digunakan pada proses } \\
\text { editing video } 360 \text { dalam } \\
\text { tahap memotong dan } \\
\text { menggabung footage } \\
\text { video } 360 \quad \text { andikasi } \\
\text { - Unity } 3 D 5.6 \quad \\
\text { Digunakan pada tahapan } \\
\text { membentuk a a }\end{array}$} \\
\hline - Proces & \\
\hline - Monito & \\
\hline - RAM 4GB DDR-L & \\
\hline - Hardisk 500GB & \\
\hline Mou & \\
\hline XUS K1 & \\
\hline DJI Drone Phantom 3 & \\
\hline Spesifikasi & \\
\hline & \\
\hline - VideoFile : AVI, & \\
\hline $\begin{array}{l}\text { AVC, H.264, MOV, } \\
\text { MP4 }\end{array}$ & \\
\hline Samsung Gear 360 & \\
\hline
\end{tabular}


E-Journal Teknik Informatika Vol 11, No.1 (2017) ISSN : 2301-8364

\begin{tabular}{|c|c|}
\hline $\begin{array}{l}\text { Spesifikasi : } \\
\text { - Frame Rates : 60, } 30 \\
\text { FPS } \\
\text {-Memori Internal : } \\
1000 \mathrm{MB} \\
\text { Video File Format : } \\
\text { MOV } \\
\text { Video Resolution : } \\
1080 \mathrm{p}, 720 \mathrm{p}, 480 \mathrm{p} \\
\text { Dimension : } 66.7 \mathrm{x} \\
56.2 \mathrm{x} 60 \mathrm{~mm} \\
\text { Weight : } 153 \mathrm{~g}\end{array}$ & $\begin{array}{l}\text { Virtual Reality Video } 360 \\
\text { Maengket } \\
\text { - Gear } 360 \text { Action } \\
\text { Director } \\
\text { Digunakan pada proses } \\
\text { Stiching Video } 360 \text { dalam } \\
\text { format equirectangular }\end{array}$ \\
\hline
\end{tabular}

\section{B. Tahap Pertimbangan Desain}

Pada tahapan ini terdapat dua poin dalam mengelolah pertimbangan desain dari aplikasi yaitu:

\section{Metafora Desain}

Dalam merancang aplikasi Maengket 360 penulis menggunakan acuan dari tulisan hasil pendataan Warisan Budaya Takbenda yang berjudul "Tari Maengket" juga dari buku "Sejarah Minahasa" (Jessy Wenas, 2007), dengan pilihan 3 menu babak menari dari tarian Maengket

\section{Tipe Informasi}

Tipe Informasi ini berisi tentang table yang menguraikan format dan jenis komponen multimedia pada saat aplikasi Maengket360 dibuat.

Tabel 3. Tabel Format dan Tipe Informasi

\begin{tabular}{|c|c|c|}
\hline NO & JENIS & FORMAT \\
\hline 1 & Gambar & .JPEG/ .PNG/ \\
\hline 2 & Objek 3D & .MESH/ .SCENE \\
\hline 3 & Audio & .MP3 \\
\hline 4 & Video & .MP4 \\
\hline 5 & Animasi & .SWF \\
\hline 6 & Autorun Aplikasi & .EXE \\
\hline
\end{tabular}

3. Struktur Navigasi

Pada tahapan Struktur Navigasi penulis menggambarkan proses Navigasi dari aplikasi yang berfungsi untuk memudahkan penulis membuat alur hubungan antar scene dari aplikasi seperti yang terlihat pada gambar 3 .

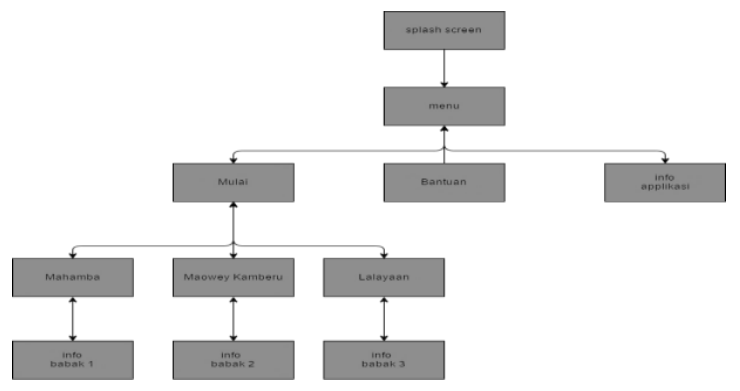

Gambar 3. Struktur Navigasi

C. Implementasi

1. Storyboard

Berikut merupakan storyboard tentang Menu Utama dari aplikasi saat pertama kali aplikasi dijalankan.

Gambar 4. Storyboard Aplikasi

\section{Computer Based Prototype}

Pada tahapan Computer Based Prototype ini menjelaskan tentang impelementasi system yang dibuat berupa penjelasan dari program yang terbagi dari beberapa asset kemudian disatukan menjadi aplikasi Virtual Reality berbasis Video 360 derajat tari-tarian Adat Suku Minahasa berikut merupakan tampilan setiap interface pada aplikasi.

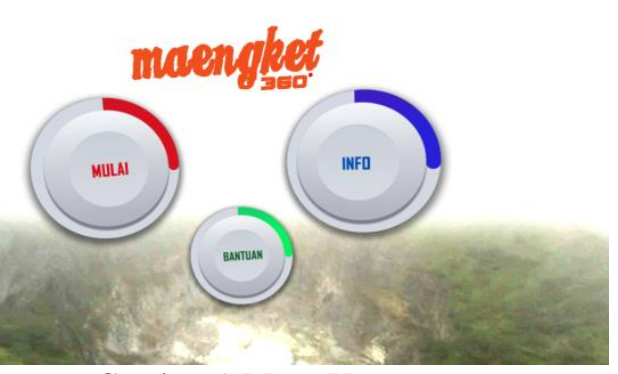

Gambar 5. Menu Utama 
Tampilan awal aplikasi yang berisi tombol mulai,tombol bantuan dan tombol scene info.

Gambar 6. Bantuan

Tampilan scene bantuan yang berisi cara penggunaan aplikasi dengan mode virtual reality menggunakan retricle pointer enter untuk memanggil fungsi masuk.

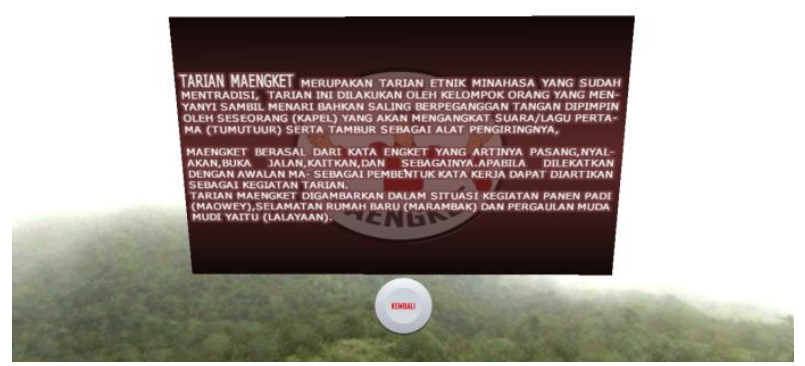

Gambar 7. Info

Tampilan pada Gambar 7 merupakan tampilan info tentang penjelasan tarian Maengket secara garis besar.

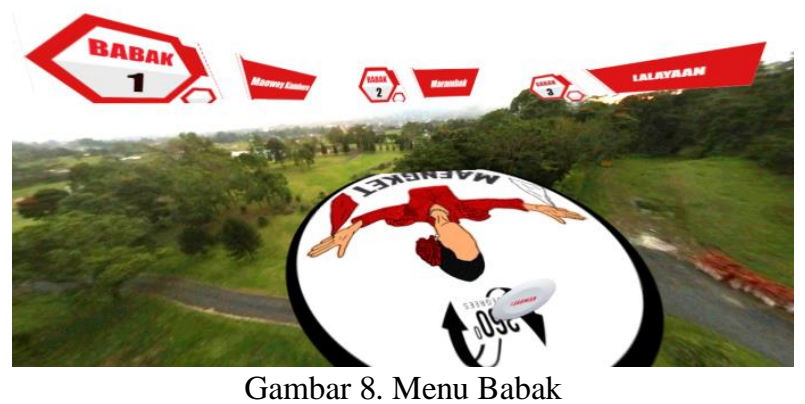

Dalam tampilan menu babak user dapat memilih urutan babak yang terdapat pada tarian Maengket

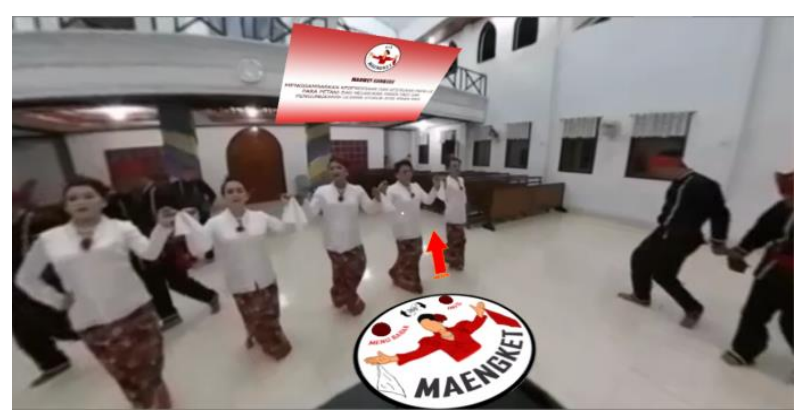

Gambar 9. Babak 1
Tampilan pada gambar 9 merupakan tampilan video 360 babak 1 dan terdapat tombol info untuk menampilkan keterangan tarian babak 1

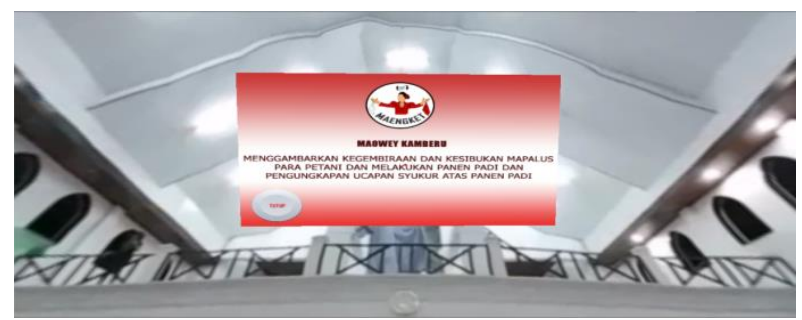

Gambar 10. Info Babak

Info babak dalam scene babak merupakan foto yang berformat .png yang menampilkan info dari babak tarian yang ditampilkan.

\section{Beta Testing}

Beta Testing merupakan pengujian akhir dari aplikasi dimana pada tahapan ini penulis menguji fungsi perpindahan scene dari tombol yang ada aplikasi Maengket360.

\begin{tabular}{|c|c|c|c|}
\hline No & Rancang Proses & $\begin{array}{|ll|}\text { Hasil } & \text { Yang } \\
\text { Dihargeplan } & \\
\end{array}$ & Hasil \\
\hline 1 & $\begin{array}{l}\text { Reticle Pointer Enter" } \\
\text { "Mula'" }\end{array}$ & $\begin{array}{l}\text { Menampilkan } \\
\text { Scene Menu Babak: }\end{array}$ & berhasil \\
\hline 2 & $\begin{array}{l}\text { Reticle Pointer Enter" "Info" } \\
\text { dalam menu utama }\end{array}$ & \begin{tabular}{|l|} 
Menampilisan \\
Scene Info \\
Mangkat
\end{tabular} & berhasil \\
\hline 3 & $\begin{array}{l}\text { Reticle Pointer Enter } \\
\text { "Kembali" pada scene info } \\
\text { di menu utama }\end{array}$ & $\begin{array}{l}\text { kembali ke scene } \\
\text { Meru Utams }\end{array}$ & berhasil \\
\hline 4 & 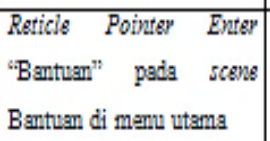 & \begin{tabular}{ll|}
\multicolumn{2}{|l|}{ Menampilkan } \\
Scens $\quad$ Bantuan \\
Aplikasi
\end{tabular} & berhasil \\
\hline 5 & \begin{tabular}{lrc|} 
Reticle Pointer & Enter \\
"Kembali" pada & scens \\
Bentuan di menu utama
\end{tabular} & $\begin{array}{l}\text { kembali ke scens } \\
\text { Menu Utama }\end{array}$ & berhasil \\
\hline 6 & $\begin{array}{l}\text { Reticle Pointer Enter } \\
\text { "Babal: 1" }\end{array}$ & \begin{tabular}{ll|} 
Memulai & Vidso \\
Babak: 1 & \\
\end{tabular} & berhasil \\
\hline 7 & $\begin{array}{l}\text { Reticle Pointer Enter } \\
\text { "Babal: } 2 "\end{array}$ & \begin{tabular}{ll|} 
Memulai & Tidso \\
Babal: 2 & \\
\end{tabular} & berhasil \\
\hline 8 & $\begin{array}{l}\text { Reticle Pointer Enter } \\
\text { "Babal: 3" }\end{array}$ & \begin{tabular}{ll|} 
Memulai $\quad$ Vidsoo \\
Babal: 3 & \\
\end{tabular} & berhasil \\
\hline 9 & $\begin{array}{l}\text { Reticle Pointer Enter" "Info" } \\
\text { pada tampilan babal: } 1\end{array}$ & $\begin{array}{l}\text { Menampillian } \\
\text { katerangan tarian } \\
\text { babak: } 1\end{array}$ & Berhasil \\
\hline
\end{tabular}


E-Journal Teknik Informatika Vol 11, No.1 (2017) ISSN : 2301-8364

\begin{tabular}{|c|c|c|c|}
\hline 10 & $\begin{array}{l}\text { Reticle Pointer Enter" "Info" } \\
\text { pada tampilan babak } 2\end{array}$ & $\begin{array}{l}\text { Menampilikan } \\
\text { keterangan tarian } \\
\text { babak } 2\end{array}$ & berhasil \\
\hline 11 & $\begin{array}{l}\text { Reticle Pointer Enter "Info" } \\
\text { pada tampilan babal: } 3\end{array}$ & $\begin{array}{l}\text { Menampilkan } \\
\text { keterangan tarian } \\
\text { babak } 3\end{array}$ & berhasil \\
\hline 12 & $\begin{array}{ccc}\text { Reticle } & \text { Pointer } & \text { Enter } \\
\text { "Menu } & \text { babak" } & \text { pada } \\
\text { tampilan babak } 1 & \end{array}$ & $\begin{array}{l}\text { Kembali ke scene } \\
\text { Menu Babak: }\end{array}$ & berhasil \\
\hline 13 & $\begin{array}{ccc}\text { Reticle } & \text { Pointer } & \text { Enter } \\
\text { "Menu } & \text { babak" } & \text { pada } \\
\text { tampilan babak: } 2 & \end{array}$ & $\begin{array}{l}\text { Kembali ke scene } \\
\text { Menu Babak }\end{array}$ & berhasil \\
\hline 14 & $\begin{array}{lrr}\text { Reticle } & \text { Pointer } & \text { Enter } \\
\text { "Menu } & \text { babal:" } & \text { pada } \\
\text { tampilan babal: } 3 & \end{array}$ & $\begin{array}{l}\text { Kembali ke scene } \\
\text { Menu Babak }\end{array}$ & berhasil \\
\hline 15 & $\begin{array}{llr}\text { Raticle } & \text { Pointer } & \text { Entep } \\
\text { "Tutup" } & \text { pada } & \text { tampilan } \\
\text { babal: } 1 & & \end{array}$ & $\begin{array}{l}\text { Menutup Info pada } \\
\text { babak: } 1\end{array}$ & berhasil \\
\hline 16 & $\begin{array}{llr}\text { Reticle } & \text { Pointer } & \text { Entep } \\
\text { "Tutup" } & \text { pada tampilan } \\
\text { babal: } 2 & & \end{array}$ & $\begin{array}{l}\text { Menutup Info pada } \\
\text { babak: } 2\end{array}$ & berhasil \\
\hline 17 & $\begin{array}{llr}\text { Reticle } & \text { Pointer } & \text { Enter } \\
\text { "Tutup" } & \text { pada } & \text { tampilan } \\
\text { babak } 3 & & \end{array}$ & $\begin{array}{l}\text { Menutup Info pada } \\
\text { babak: } 3\end{array}$ & berhasil \\
\hline
\end{tabular}

Gambar 11. Beta Testing

Berdasarkan Gambar 11 dapat disimpulkan bahwa hasil dari pengujian beta testing berjalan dengan baik dimana semua hasil uji coba pada setiap scene berhasil dilakukan tanpa error pada aplikasi.

\section{Evaluasi}

Setelah tahap Prototype dilakukan penulis menerapkan tahap ini dengan delapan aturan emas desain antarmuka (The Eight Golden Rules Of Interface Design ) yang dikemukakan oleh Ben Shneiderman, Gambar 12 berikut merupakan hasil evaluasi aplikasi.

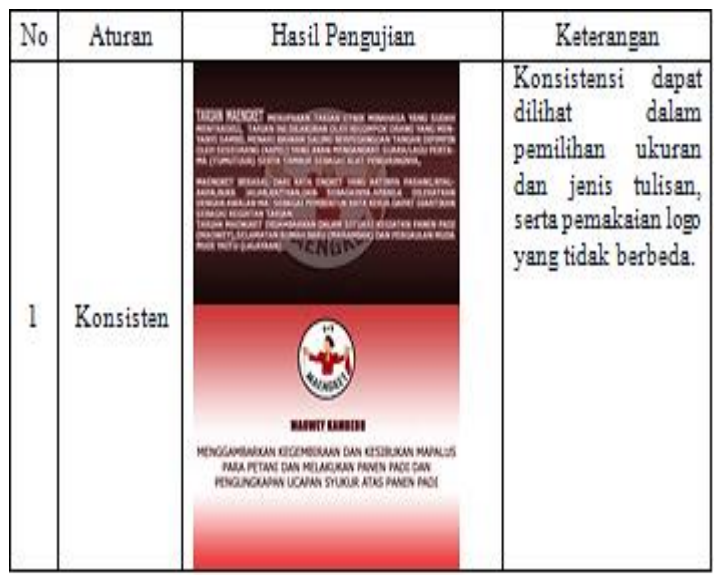

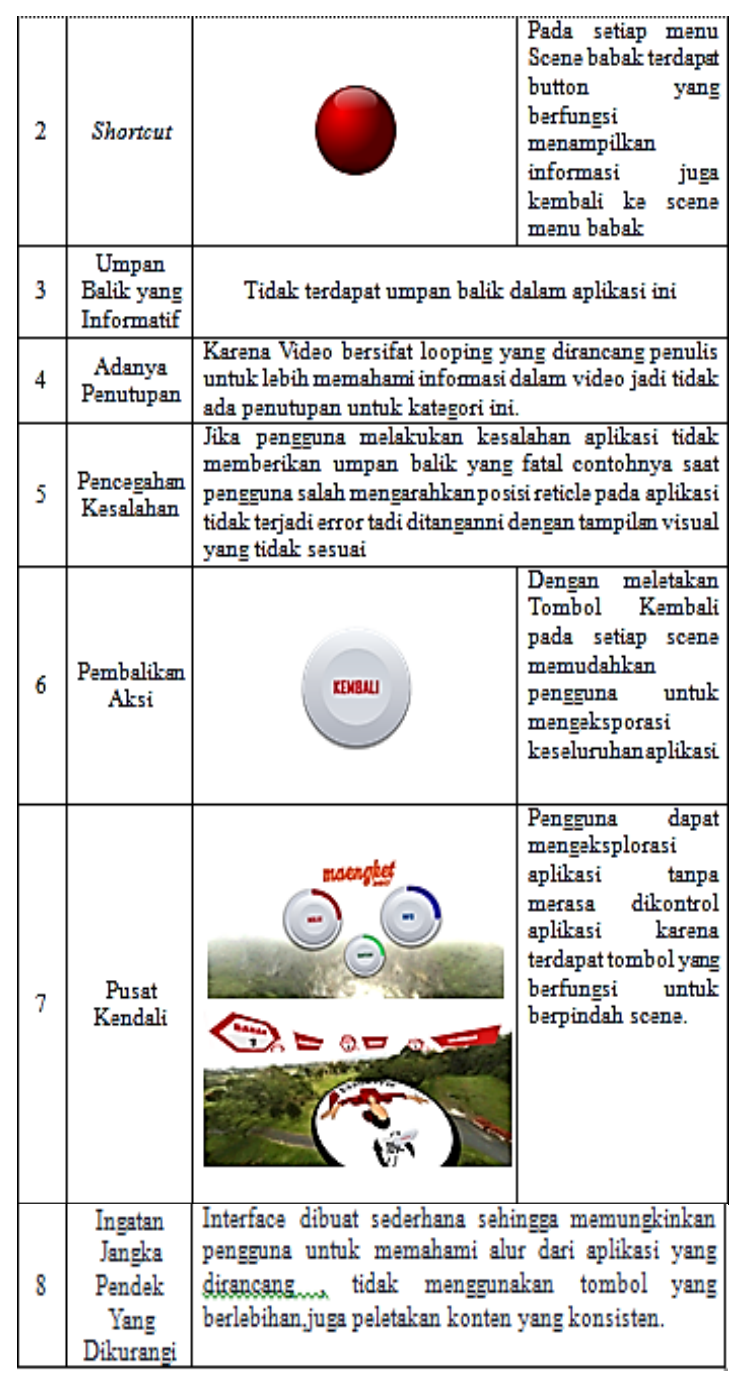

Gambar 12. Evaluasi Aplikasi

\section{PENUTUP}

\section{A. KESIMPULAN}

Berdasarkan analisis, perancangan, implementasi dan pengujian yang telah dilakukan terhadap aplikasi Maengket360, dapat diambil kesimpulan sebagai berikut:

1. Aplikasi Maengket360 sebagai media Dokumentasi nilai Budaya berbasis virtual reality telah berhasil dibangun dengan menggunakan metode Multimedia System of Design and Development (IMSDD).

2. Aplikasi Maengket360 dapat berjalan sesuai dengan fungsinya.

3. Aplikasi Maengket360 dapat menampilkan video 360 beserta informasi didalamnya.

4. Aplikasi Maengket360 dapat membantu melestarikan nilai budaya yang berada di Sulawesi Utara. 


\section{B. SARAN}

Setelah dilakukan penelitian ini, Disarankan :

1. Agar pihak universitas dapat membantu memperkenalkan aplikasi ini dengan harapan dapat menjadi salah satu media yang dapat mempromosikan juga melestarikan nilai budaya khususya tarian adat suku Minahasa tari Maengket.

2. Untuk penelitian selanjutnya agar dapat mengembangkan serta memperbanyak vitur dalam aplikasi Virtual Reality berbasis video 360 .

3. Menambahkan basis pengetahuan untuk SIT dan topik lainnya.

\section{DAFTAR PUSTAKA}

[1] Dastbaz, Mohammad. 2003. Designing Interactive Multimedia Systems. McGraw-Hill,New York.

[2] Wulur H. W. 2014. "Aplikasi Virtual tour Tempat Wisata Alam di Sulawesi Utara". E-journal Teknik Informatika, Volume 6, No. 1, ISSN : 2301-8364.

[3] https://unity3d.com/. Diakses pada tanggal 13 September 2016

[4] Shite Berta, Samopa Febriliyan, \& Sani. A. N. 2013. "Pembuatan Aplikasi 3D Viewer Mobile dengan Menggunakan Teknologi Virtual Reality (Studi Kasus: Perobekan Bendera Belanda di Hotel Majapahit)". jurnal teknik pomits, Volume 2, No. 2, ISSN : 2337-3539 (2301-9271 Print)

[5] Shneiderman B. 1998. Designing The User Interface: Strategic For Effective HCI. 3 rd Edition. Addison Wesley

[6] Magdalena J.Sumarauw (2013)."Tari Maengket". Kepel Press. Yogyakarta.

[7] Binanto. 2010. Multimedia Digital - Dasar Teori dan Pengembangannya, Penerbit Andi. Jakarta.

[8] Kurniawan A. S., 2011. "Visualisasi Tiga Dimensi Proses Fotosintesis Tumbuhan Menggunakan Particle System (Efek Partikel) (Studi Kasus SDN Kebayoran Lama Selatan 13 Pagi)”. Skripsi S1 Sekolah Tinggi Fakultas Sains dan Teknologi Universitas Islam Negeri (UIN), Jakarta.

[9] Sutrisno T., 2007. "Iklan Audio Visual D3 Ilmu Komputer Universitas Sebelas Maret”. Skripsi Diploma III Fakultas Matematika dan Ilmu Pengetahuan Alam Universitas Sebelas Maret, Surakarta.

[10]https://developer.android.com/guide/topics/sensors/sen sors_overview.html. Diakses pada tanggal 21 Januari 2012 [11]https://developer.android.coam/guide/topics/media/me dia-formats.html.Diakses pada tanggal 21 Januari 2012.

Sekilas Tentang Penulis dengan Nama lengkap Xenna Semuel Rambing, anak tunggal. Lahir di Lembean, Minahasa Utara, Sulawesi Utara pada tanggal 5 Juli 1994. Dengan alamat tempat tinggal sekarang di Pineleng desa Sea 1. Saya mulai menempuh pendidikan di sekolah dasar Negeri Kombi (2000 - 2006). Setelah itu saya melanjutkan pendidikan tingkat pertama di SMP Katolik Stella Maris Tomohon (20062009).Selanjutnya saya menempuh pendidikan Ke Sekolah Tingkat Atas, di SMA Katolik Rex Mundi Manado (2009 - 2012). Setelah itu, di Tahun 2012 saya melanjukan pendidikan ke salah satu perguruan tinggi yang berada di Manado yaitu Universitas Sam Ratulangi Manado, dengan mengambil Program Studi S-1 Teknik Informatika di Jurusan Elektro, Fakultas Teknik. Penulis membuat Skripsi demi memenuhi syarat memperoleh gelar Sarjana (S1) dengan penelitian berjudul Virtual Reality Berbasis Video 360 Derajat Pada Tari-Tarian Adat Suku Minahasa yang dibimbing oleh dua dosen pembimbing yaitu Virginia Tulenan, S.Kom.,MTI dan Xaverius Najoan, ST, MT serta pada tanggal 19 Juni 2017 penulis resmi lulus dari Program Studi Teknik Informatika Jurusan Elektro Fakultas Teknik Universitas Sam Ratulangi Manado dan menyandang gelar Sarjana Komputer 
E-Journal Teknik Informatika Vol 11, No.1 (2017) ISSN : 2301-8364 